\title{
ON THE DETERMINATION OF A CONVERSION FACTOR FROM LABELLED THYMIDINE INCORPORATION BY BACTERIA TO CELL PRODUCTION IN A SUB-TROPICAL ESTUARY: PRELIMINARY RESULTS
}

\author{
José Juan Barrera-Alba ${ }^{1}$; Sônia Maria Flores Gianesella ${ }^{l}$; Flávia Marisa Prado Saldanha-Corrêa ${ }^{I}$; \\ \& Gleyci Aparecida Oliveira Moser ${ }^{2}$ \\ ${ }^{1}$ Instituto Oceanográfico da Universidade de São Paulo \\ (Praça do Oceanográfico, 191 05508-900, São Paulo, SP, Brasil) \\ juanalba@usp.br \\ ${ }^{2}$ Faculdade de Ciências Ambientais - Oceanografia \\ Centro Universitário Monte Serrat - UNIMONTE. \\ (Campus Ponta da Praia, Av. Saldanha da Gama, 89, 11030-220, Santos, SP, Brasil)
}

\begin{abstract}
Bacterial carbon production has become a key parameter in quantifying carbon flows through aquatic food webs (Smith \& Azam, 1992). Measurement of ${ }^{3} \mathrm{H}$-Thymidine $\left({ }^{3} \mathrm{H}-\mathrm{TdR}\right)$ incorporation into bacterial DNA is a useful method to determine bacterial cell production in seawater, freshwater and sediment (Fuhrman \& Azam, 1980; Riemann et al., 1982; Moriarty \& Pollard, 1981). Fuhrman \& Azam (1980) related the need of an adequate conversion factor to estimate of bacterial cell production from ${ }^{3} \mathrm{H}-\mathrm{TdR}$ incorporation into DNA, and since then several authors have discussed methodological aspects.
\end{abstract}

On the basis of theoretical considerations, a factor ranging between 0.2 to $1.3 \times 10^{18}$ cells per mol of incorporated ${ }^{3} \mathrm{H}-\mathrm{TdR}$ has been proposed (Fuhrman \& Azam, 1980). Empirical conversion factors have also been determined by simultaneous measurements of rates of ${ }^{3} \mathrm{H}-\mathrm{TdR}$ incorporation and cell production computed from direct counts for different marine environments around the world. The large range of variation for this factor may be found among these studies due to both high conversion factors derived from $\left({ }^{3} \mathrm{H}-\mathrm{TdR}\right)$ isotope dilution (Moriarty, 1984) and to the characteristics of the different environment and climatic condition under consideration, and it was demonstrated that the coupling between population growth and ${ }^{3} \mathrm{H}-\mathrm{TdR}$ is not uniform (Riemann et al., 1987). Up to this moment, no conversion factor was proposed in the literature on tropical or sub-tropical estuaries, as well. In this sense, the present work represents a first effort to determine a conversion factor for a sub-tropical estuary.

On May 2004, estuarine water (salinity 22; temperature $24^{\circ} \mathrm{C}$ ) from the inner portion of the Cananéia Estuarine System, at Cananéia Sea $\left(25^{\circ} 00^{\prime} \mathrm{S}\right.$, $\left.47^{\circ} 54^{\prime} \mathrm{W}\right)$, Brazil, was collected to estimate an empirical conversion factor for labeled thymidine incorporation to cells produced. Cell production rate

$\overline{\text { Contr. no. } 863}$ do Inst. oceanogr. da Usp. was empirically estimated on dilution culture experiment by correlation of changes in cell abundance and ${ }^{3} \mathrm{H}-\mathrm{TdR}$ uptake rates (Kirchman et al., 1982). The experiment used bacterial culture media prepared by filtering an aliquot of estuarine water sample onto $1 \mu \mathrm{m}$ NUCLEPORE polycarbonate filters. Another aliquot was filtered through a GELMAN pleated capsule with $0.2 \mu \mathrm{m}$ Versapor membrane. The sample filtered in $1 \mu \mathrm{m}$ was then diluted in a ratio of $1: 10$ with the $0.2 \mu \mathrm{m}$ filtered water. A total bacterial culture volume of $2000 \mathrm{ml}$ was incubated for $40 \mathrm{~h}$ in the dark, at room temperature, which varied from 22.5 to $26.2^{\circ} \mathrm{C}$. The culture was sub-sampled at $5 \mathrm{~h}$ intervals for determination of cell abundance and bacterial secondary production experiments $\quad{ }^{3} \mathrm{H}-\mathrm{TdR}$ incorporation rate). For cell abundance determination three aliquots of $2-3 \mathrm{ml}$ were stained with DAPI $(1 \mu \mathrm{g}$ $\mathrm{ml}^{-1}$ final concentration) for 10 minutes and filtered onto black $0.2 \mu \mathrm{m}$ PORETICS polycarbonate membrane filters. The filters were laid on microscope slides between layers of immersion oil, and cells were counted under a ZEISS JENALUMAR epifluorescence microscope under $1000 \mathrm{x}$ magnification using a UV filter combination (Porter \& Feig, 1980). Secondary production followed the method proposed by Smith \& Azam (1992) but using ${ }^{3} \mathrm{H}$-TdR instead of ${ }^{3} \mathrm{H}$-Leucine. Ten sterile $1.5 \mathrm{ml}$ capacity micro-centrifuge tubes received $20 \mu 1{ }^{3} \mathrm{H}$ TdR (Thymidine-(Methyl- ${ }^{3} \mathrm{H}$ ) SIGMA FW 242.2; 0.9 $\mathrm{mCi} \mathrm{ml}{ }^{-1} 64 \mathrm{Ci} \mathrm{mmol}^{-1}$ ) to yield a final concentration of $20 \mathrm{nM}$ upon the addition of $1.23 \mathrm{ml}$ of culture media. Two of these tubes received immediately $50 \mu \mathrm{l}$ of formaldehyde p.a. $37 \%$ for representing the blank and the other eight were incubated for an hour in the dark, at room temperature. Incubation was stopped by the addition of $50 \mu 1$ of formaldehyde p.a. $37 \%$. Samples were kept at $4^{\circ} \mathrm{C}$ until laboratory processing. Samples received $7 \mu 1$ of ice-cold TCA $100 \%$ (final concentration 5\%) and after $30 \mathrm{~min}$ they were centrifuged (EPPENDORF 5804R) at $4^{\circ} \mathrm{C}$ for $15 \mathrm{~min}$ 
at $12000 \mathrm{rpm}$ and the liquid was aspirated. The samples were washed by the addition of $1.25 \mathrm{ml}$ of ice-cold TCA 5\%, vortex mixed, centrifuged and aspirated. This process was repeated three times and then $1.5 \mathrm{ml}$ of scintillation cocktail (Bray, 1960) was added and vortexed. The micro-centrifuge tubes were placed into scintillation vials and radioassayed in a liquid scintillation spectrometer (PACKARD TriCarb1600). DPM counts were converted to mols of incorporated ${ }^{3} \mathrm{H}-\mathrm{TdR} \mathrm{l}^{-1} \mathrm{~h}^{-1}$ according to the equation proposed by Bell (1993):

$$
v=\left(\frac{\left[d p m_{\text {sample }}-d p m_{\text {blank }}\right] *\left(4.5^{*} 10^{-13}\right)}{S A^{*} t^{*} V}\right) * 10^{-3}\left(\mathrm{~mol}^{3} \mathrm{H}-\mathrm{TdR}^{-1} \mathrm{~h}^{-1}\right)
$$

where $4.5 \times 10^{-13}$ is the number of curies per dpm; SA is the specific activity of the ${ }^{3} \mathrm{H}-\mathrm{TdR}$ added to the sample in curies per mmol; $t$ is the incubation time in $\mathrm{h} ; V$ is the incubation volume in 1 ; and $10^{-3}$ is the correction from mmol to mol.

The conversion factor (C) from ${ }^{3} \mathrm{H}-\mathrm{TdR}$ incorporation to the number of cells produced at the same time interval was computed by the derivative method described by Kirchman et al. (1982) and modified by Bell et al. (1983):

$$
C=\frac{\mu N(t)}{v(t)} \text { cells }\left(\mathrm{mol}^{3} \mathrm{H}-\mathrm{TdR}\right)^{-1}
$$

where $\mathrm{N}(\mathrm{t})$ and $v(\mathrm{t})$ are, respectively, the bacterial abundance and the incorporation rate at any time, and $\mu$ is the slope of $\ln N(t)$ versus time, i.e. the growth rate $\left(\mathrm{h}^{-1}\right)$.

The conversion factor was also computed by the integrative method described by Riemann et al. (1987) which considers the number of bacterial cells produced at a selected time interval of the experiment (the final abundance minus the initial abundance at the time interval) divided by the total amount of ${ }^{3} \mathrm{H}-\mathrm{TdR}$ incorporated during the same interval:

$$
C=\frac{N\left(t_{f}\right)-N\left(t_{i}\right)}{v_{\Delta t}} \text { cells }\left(\mathrm{mol}^{3} \mathrm{H}-\mathrm{TdR}\right)^{-1}
$$

Another way to calculate the conversion factor was presented by Ducklow \& Hill (1985):

$$
C=\frac{\delta^{*} N o}{e^{b}} \approx \frac{\mu^{*} N o}{T o} \operatorname{cells}\left(\mathrm{mol}^{3} \mathrm{H}-\mathrm{TdR}\right)^{-1}
$$

where $\mathrm{N}_{0}$ and $\mathrm{T}_{\mathrm{o}}$ are, respectively, the bacterial abundance and the incorporation rate at time $=0, \mu$ is the slope of linear regression of $\ln (\mathrm{N})$ vs. time, and $\delta$ and $\mathrm{b}$ are respectively the slope and $y$-intercept of linear regression of $\ln (\mathrm{T}) \mathrm{vs}$. time.

As bacterial grazing was minimized by filtration and dilution with $0.2 \mu \mathrm{m}$-filtered water, bacterial abundance increased exponentially as indicated on Figure 1A. After 25h of incubation, the growth rate decreased, and the last 10 hours represent a stationary phase. A maximum cell number of $1.1 \times 10^{9}$ cells $1^{-1}$ was recorded at the end of the experiment (Table 1). The maximum growth rate was $0.0421 \mathrm{~h}^{-1}$, a value comparable with those obtained by Kirchman \& Hoch (1988) in the Delaware Estuary (Table 2). The incorporation rate of ${ }^{3} \mathrm{H}-\mathrm{TdR}$ both per $\mathrm{h}^{-1}$ and per cell, showed an increase after $15 \mathrm{~h}$, corresponding to the end of the exponential phase of the growth curve (Figs 1A and 1C). Some researchers observed an uncoupling between TdR incorporation and cell number increase, especially due to a lag phase experienced by bacteria after the beginning of the experiment with filtered or diluted water (Rieman et al., 1987).

The conversion factors obtained both by derivative (equation 2) and integrative (equation 3) methods computed for the first $5 \mathrm{~h}$ interval were higher than the other ones showed (Fig. 1B and Table 1). Kirchman \& Hoch (1988) demonstrated that an initial isotope dilution of the added ${ }^{3} \mathrm{H}-\mathrm{TdR}$ occurs due to high extra-cellular concentrations of amino-acids, and $\mathrm{TdR}$ as well, released as a consequence of the initial filtration. According to these authors, this fact could explain the high initial conversion factors obtained and represents no ecological relevance. So, in general, the initial conversion factors $(<5 \mathrm{~h})$ are not included in average value computation. Thymidine concentration used in the present work was high enough to avoid isotope dilution, as well as to hamper the thymidine degradation due to the action of thymidine phosphorilase (Moriarty, 1984). We used this TdR concentration based in previous experiment to settle the appropriate concentration to be used (Gianesella et al., unpublished data). The average conversion factor obtained was $0.94 \times 10^{18}$ and $1.80 \times 10^{18}$ cells $\mathrm{mol}^{-1}{ }^{3} \mathrm{H}-$ $\mathrm{TdR}$, respectively by the derivative (eq. 2) and integrative (eq. 3) methods, when all conversion factors are considered (Table 2). Without the initial high value, mean conversion factors were $0.50 \times 10^{18}$ and $0.52 \times 10^{18}$ cells mol ${ }^{-1}{ }^{3} \mathrm{H}-\mathrm{TdR}$, respectively. These values are in the theoretical range proposed by Fuhrman \& Azam (1980) and are similar to the theoretical value also proposed by Bell (1993). In spite of being lower than other values presented in Table 2, like the range obtained by Kirchman \& Hoch (1988) for the Delaware Estuary. Conversion factor calculated by Ducklow \& Hill (1985) varied between 5.32 and $5.64 \times 10^{18}$ cells $\mathrm{mol}^{-1}{ }^{3} \mathrm{H}-\mathrm{TdR}$, higher to those presented by these authors. However, as this method is 
based on the initial incorporation rate, it can be biased by the artifacts discussed by Kirchman \& Hoch (1988), resulting in an overestimated conversion factor. These results show the difficulty of this task since there is a high variation depending on the considered algorithm, and there is little information about which one was used by each author to compare our results.
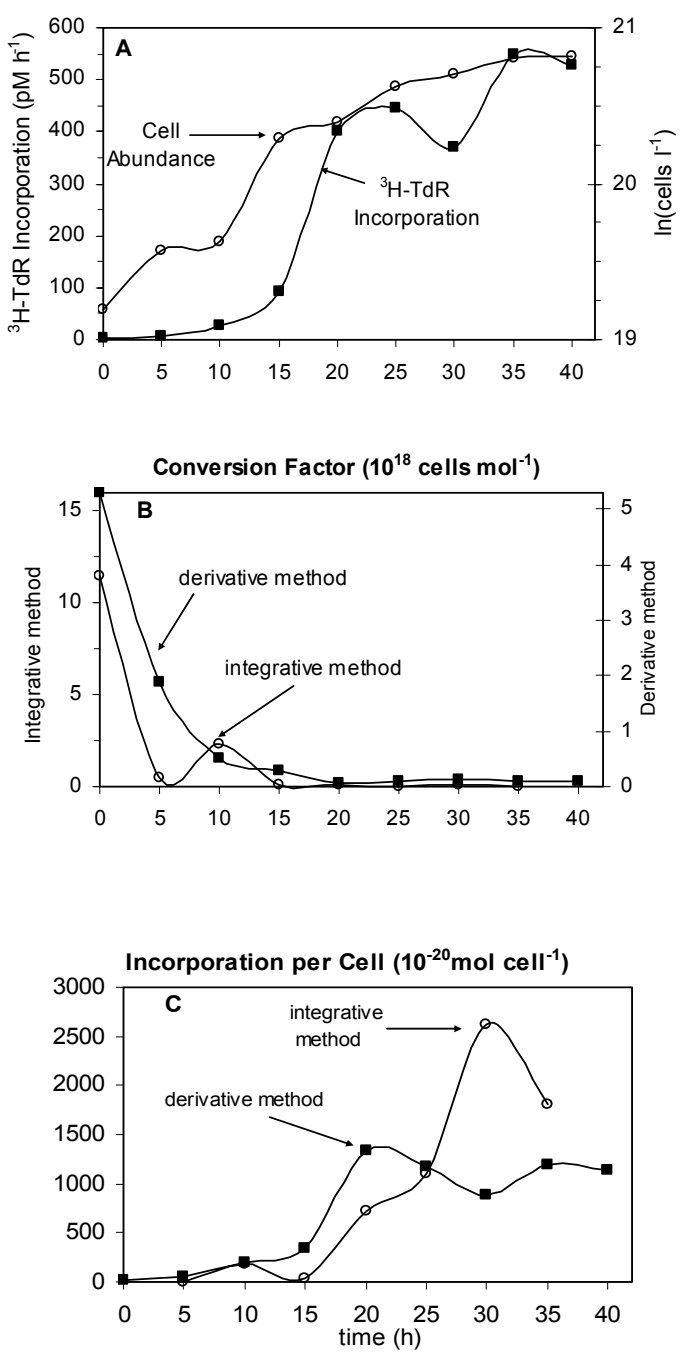

Fig. 1. Bacterial growth experiment in May 2004 to estimate conversion factor for the thymidine $\left({ }^{3} \mathrm{H}-\mathrm{TdR}\right)$ method. (A) Bacterial abundance (cells ${ }^{-1}$ ) and Thy incorporation rate $\mathrm{pM}$ $\left({ }^{3} \mathrm{H}-\mathrm{TdR}\right) \mathrm{h}^{-1}$; (B) Conversion factors $\left(10^{18}\right.$ cells $\left(\mathrm{mol}^{3} \mathrm{H}-\right.$ $\mathrm{TdR}^{-1}$ ) calculated by the derivative (eq. 2) and integrative (eq. 3) methods and (C) ${ }^{3} \mathrm{H}-\mathrm{TdR}$ Incorporation rates of per cell $\left(10^{-20} \mathrm{~mol}^{3} \mathrm{H}-\mathrm{TdR}\right.$ cell $\left.{ }^{-1}\right)$.
It should be noted that even though the present paper considered a single trial from a single location, it is a necessary step to establish an appropriate set ofconversion factors to a sub-tropical estuary, providing a basis to compare the obtained factors with those obtained from temperate environments. TdR metabolism could also result in tritium incorporation in macromolecules indistinguishable from DNA by the simple extraction and hydrolysis procedures typically used to separate incorporated from unincorporated $\mathrm{TdR}$ (Hollibaugh, 1988). A number of authors have reported that ${ }^{3} \mathrm{H}$-TdR labels other macromolecules as well as DNA, and it can be a significant source of error in bacterioplankton productivity estimates in certain environments (see in Hollibaugh, 1988). But, in spite of this, and based on: 1- the theoretical assumption that ${ }^{3} \mathrm{H}-\mathrm{TdR}$ is incorporated exclusively into cellular DNA (Fuhrman \& Azam, 1980); 2- that in most environments, ${ }^{3} \mathrm{H}-\mathrm{TdR}$ appears to be incorporated specifically, or almost specifically, into DNA by microbial assemblages (see in Hollibaugh, 1988); and 3- that our conversion factors, both calculated by integrative and derivative methods, were similar to those found in different estuarine systems and inside the range of theoretical ones, the present data constitute a reference for future studies on bacterial production in Brazilian estuaries.

The great variety of environmental conditions in tropical estuaries both due to hydrographic gradients and to temporal variation (tidal stages, annual cycle, etc) can hinder the establishment of a unique conversion factor. Another source of uncertainty for the measurement of bacterial production is the carbon content per bacterial cell. Therefore, a complete study to provide both a set of conversion factors and an estimation of carbon content per bacterial cell over an annual cycle, comparing different estuaries or along salinity gradients and tidal stages (e.g.) is, actually, necessary to an improved determination of bacterial productivity.

\section{AcKNowledgments}

We thank Dr. Rubens Mendes Lopes of the Instituto Oceanográfico USP (IOUSP) for his valuable help during field work and the crew of " $\mathrm{B} / \mathrm{Pq}$. Albacora" for their help during sampling. We also thank Dra. June Ferraz Dias (IOUSP), for allowing us to use the micro-centrifuge. 
Table 1. Mean cell abundance $(\mathrm{N})$, standard deviation of abundance and incorporation rates of ${ }^{3} \mathrm{H}-\mathrm{TdR}$ along the incubation experiment.

\begin{tabular}{|c|c|c|c|c|c|c|c|c|c|}
\hline Time $(\mathrm{h})$ & 0 & 5 & 10 & 15 & 20 & 25 & 30 & 35 & 40 \\
\hline $\mathrm{N}\left(\mathrm{x} \quad 10^{8}\right.$ cells $\left.1^{-1}\right)$ & 2.16 & 3.15 & 3.34 & 6.52 & 7.17 & 9.00 & 9.85 & 10.88 & 11.01 \\
\hline std.dev. $\left(\mathrm{x} 10^{8}\right.$ cells $\left.1^{-1}\right)$ & 0.88 & 0.89 & 0.84 & 0.85 & 0.89 & 0.93 & 0.78 & 0.75 & 0.84 \\
\hline $\mathrm{v}\left(\mathrm{x} 10^{12}\right.$ mole $\left.^{3} \mathrm{H}-\mathrm{TdR} \mathrm{l}^{-1} \mathrm{~h}^{-1}\right)$ & 1.72 & 7.00 & 27.81 & 92.18 & 402.75 & 445.37 & 369.53 & 550.26 & 528.64 \\
\hline
\end{tabular}

Table 2. Growth rate and mean conversion factors calculated for this experiment and by others authors.

\begin{tabular}{|c|c|c|c|c|}
\hline \multirow[t]{2}{*}{ Author } & \multirow[t]{2}{*}{ Study area } & \multicolumn{2}{|c|}{$\begin{array}{c}\text { Conversion factors } \\
\left(10^{18}{\left.\text { cells } \mathrm{mol}^{-1} \mathrm{TdR} \text { incorporated }\right)}\right.\end{array}$} & \multirow{2}{*}{$\begin{array}{c}\text { Growth rate } \\
\left(\mathrm{h}^{-1}\right)\end{array}$} \\
\hline & & & Method used & \\
\hline \multirow[t]{2}{*}{ present work } & Cananéia Estuary, & $0.50^{\mathrm{a}} ; 0.94^{\mathrm{b}}$ & derivative & \multirow[t]{5}{*}{0.0421} \\
\hline & Brazil & $0.52^{\mathrm{a}} ; 1.80^{\mathrm{b}}$ & integrative & \\
\hline Fuhrman \& Azam 1980 & theoretical & $0.2-1.3$ & not definided & \\
\hline Ducklow \& Hill, 1985 & Gulf Stream & 4.0 & Ducklow \& Hill & \\
\hline Alldredge et al., 1986 & Gulf Stream & 1.4 & not definided & \\
\hline Riemann et al., 1987 & Danish fjord & 1.1 & integrative & \multirow{7}{*}{$0.017-0.06$} \\
\hline Kirchman \& Hoch, 1988 & Delaware Estuary & $0.68^{\mathrm{a}}-1.53^{\mathrm{a}}$ & derivative & \\
\hline Findlay et al., 1991 & Hudson River Estuary & $\begin{array}{c}0.70^{\mathrm{a}}-1.59^{\mathrm{a}} \\
1.0\end{array}$ & $\begin{array}{l}\text { integrative } \\
\text { not definided }\end{array}$ & \\
\hline \multicolumn{2}{|l|}{ Zohary \& Robarts 1992} & 1.0 & not definided & \\
\hline Bell, 1993 & theoretical & 0.5 & not definided & \\
\hline Hoch \& Kirchman, 1993 & Delaware Estuary & 1.1 & not definided & \\
\hline Goosen et al.,1995 & Holland estuaries & 2.0 & not definided & \\
\hline \multicolumn{5}{|c|}{ a calculated without considering $<5 \mathrm{~h}$ factor conversion } \\
\hline \multicolumn{5}{|c|}{${ }^{\mathrm{b}}$ calculated considering $<5 \mathrm{~h}$ factor conversion } \\
\hline Rest of factor conversion & information about algc & & & \\
\hline
\end{tabular}

\section{REFERENCES}

Bell, R. T. 1993. Estimating production of heterotrophic bacterioplankton via incorporation of tritiated thymidine. In: Kemp, P.; Sherr, B.; Sherr, E. \& Cole, J. eds. Handbook of methods in aquatic microbial ecology. Lewis Publishers, Inc. p. 495-503.

Bell, T. B.; Ahlgren, G. M. \& Ahlgren, I. 1983. Estimating bacterioplankton production by measuring ${ }^{3} \mathrm{H}$-thymidine incorporation in a eutrophic Swedish lake. Appl. environ. Microbiol., 45:1709-1721.

Bray, G. A. 1960. A simple efficient liquid scintillator for counting aqueous solution in a liquid scintillation counter. Analyt. Biochem., 1:279-285.
Ducklow, H. W. \& Hill, S. 1985. Tritiated thymidine incorporation and the growth of heterotrophic bacteria in warm core rings. Limnol. Oceanogr., 30:260-272.

Fuhrman, J. A. \& Azam, F. 1980. Bacterioplankton secondary production estimates for coastal waters of British Columbia, Antarctica, and California. Appl. environ. Microbiol., 39:1085-1095.

Hollibaugh, J. T. 1988. Limitations of the $\left.{ }^{3} \mathrm{H}\right]$ thymidine method for estimating bacterial productivity due to thymidine metabolism. Mar. Ecol. Prog. Ser., 43:19-30.

Kirchman, D. L. \& Hoch, M. P. 1988. Bacterial production on Delaware Bay estuary estimated from thymidine and leucine incorporation rates. Mar. Ecol. Prog. Ser., 45:169-178. 
Kirchman, D.; Ducklow, H. \& Mitchell, R. 1982 Estimates of bacterial growth from changes in uptake rates and biomass. Appl. environ. Microbiol., 49:12961307.

Moriarty, D. J. W. 1984. Measurements of bacterial growth rates in some marine systems using the incorporation of tritiated thymidine into DNA. In: Hobbie, J. E. \& Williams, P. J. le B eds. Heterotrophics activity in the sea. New York, Plenum Press. p. 217-231.

Moriarty, D. J. W. \& Pollard, P. C. 1981. DNA synthesis as a measure of bacterial productivity in seagrass sediments. Mar. Ecol. Prog. Ser., 5:151-156.

Porter, K. G. \& Feig, Y. S. 1980. The use of DAPI for identifying and counting aquatic microflora. Limnol. Oceanogr., 25(5):943-948.
Riemann, B.; Fuhrman, J. A. \& Azam, F. 1982. Bacterial secondary production in freshwater measured by ${ }^{3} \mathrm{H}-$ thymidine incorporation method. Microb. Ecol., 8:101114.

Riemann, B.; Bjørnsen, P. K.; Newell, S. \& Fallon, R. 1987. Calculation of cell production of coastal marine bacteria based on measured incorporation of ${ }^{3} \mathrm{H}$-thymidine. Limnol. Oceanogr., 32:471-476.

Smith, D. C. \& Azam, F. 1992. A simple, economical method for measuring bacterial protein synthesis rates in seawater using ${ }^{3} \mathrm{H}$-leucine. Mar. microbiol. Food Webs, 6(2):107-114.

(Manuscript received 16 June 2004: revised 15 October 2004; accepted 21 October 2004) 